Portland State University

PDXScholar

\title{
Urban Non-Timber Forest Products Stewardship Practices Among Foragers in Seattle, Washington (USA)
}

\author{
Rebecca J. McLain \\ Portland State University, mclainrj@pdx.edu \\ Melissa R. Poe \\ University of Washington \\ Lauren S. Urgenson \\ University of Washington \\ Dale Blahna \\ USDA-Forest Service, Pacific Northwest Research Station \\ Lita P. Buttolph \\ Institute for Culture and Ecology
}

Follow this and additional works at: https://pdxscholar.library.pdx.edu/geog_fac

Part of the Physical and Environmental Geography Commons

Let us know how access to this document benefits you.

\section{Citation Details}

McLain, R., Poe, M. R., Urgenson, L. S., Blahna, D. J., \& Buttolph, L. P. (2017). Urban non-timber forest products stewardship practices among foragers in Seattle, washington (USA). Urban Forestry \& Urban Greening, 2836-42.

This Article is brought to you for free and open access. It has been accepted for inclusion in Geography Faculty Publications and Presentations by an authorized administrator of PDXScholar. Please contact us if we can make this document more accessible: pdxscholar@pdx.edu. 
Original article

\title{
Urban non-timber forest products stewardship practices among foragers in Seattle, washington (USA)
}

\author{
R.J. McLain ${ }^{\mathrm{a}, *, 1}$, Melissa R. Poe ${ }^{\mathrm{a}, 2}$, Lauren S. Urgenson ${ }^{\mathrm{a}, 3}$, Dale J. Blahna ${ }^{\mathrm{b}}$, Lita P. Buttolph ${ }^{\mathrm{a}, 4}$

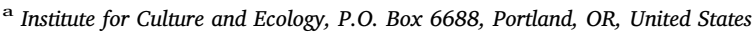 \\ b USDA Forest Service, Pacific Northwest Research Station, 400 N. 34th Street, Suite 201, Seattle, WA 98103, United States
}

\section{A R T I C L E I N F O}

\section{Keywords:}

Urban foraging

Urban forestry

Urban ecological restoration

Environmental stewardship

Urban parks

\begin{abstract}
A B S T R A C T
Our research seeks to expand the concept of urban environmental stewardship to include the everyday stewardship practices of urban nontimber forest products foragers. Ethnographic data from 58 urban foragers and 18 land stewards in the city of Seattle (USA) revealed that foragers reported using a variety of practices to enhance and minimize negative desirable species and their habitats. Many of these practices were identical to those practiced by restoration volunteers in formal programs and align with Seattle Parks Department management objectives. Foragers actively sought to learn more about what practices are sustainable; many mentored others in sustainable harvesting practices. Most foragers emphasized the importance of treating plants and their environment with respect. The land stewards voiced some concerns about foraging in city parks, but most were cautiously supportive of opening up the parks to foragers. The study results suggest that an opportunity exists for park managers to develop alliances with foragers so as to leverage foragers' everyday stewardship practices and accomplish some of their park restoration objectives. Doing so will require park managers to acknowledge the positive contributions that humans can to make novel ecosystems and foragers to develop or strengthen selfregulation norms.
\end{abstract}

\section{Introduction}

Community participation in environmental stewardship has emerged as an important strategy to expand and sustain the ecosystem services provided by nature in cities (e.g. improved air quality, storm water management, micro-climate regulation and wildlife habitat) (Romolini et al., 2012). Urban environmental stewardship includes a range of voluntary actions taken to conserve, manage, monitor, advocate for, and educate about local environments (e.g. restoration of forested parks, tree planting campaigns, and community gardens) (Campbell and Wiesen, 2011). With declining city budgets, urban stewardship offers a cost-effective means to address ecosystem needs and recovery (Sanderson and Huron, 2011; Wolf et al., 2013). Stewardship also embodies a nature-society relationship centered on caretaking and reciprocity (Campbell and Wiesen, 2011). A growing body of evidence demonstrates social and psychological benefits incurred through participating in urban stewardship including improved mental and physical health (Pillemer et al., 2010), and enhanced social cohesion and resilience (McMillen et al., 2016). These reciprocal benefits motivate participation and sustain volunteer's commitment to stewardship actions (Asah and Blahna, 2013; Moskell and Allred 2013).

Research in urban environmental stewardship has focused on formal volunteer efforts, carried out under the auspices of city governments and civil society groups (Connolly et al., 2013; Romolini et al., 2013). A presumption often exists that stewardship does not emerge from individuals working in isolation from official institutions and structures (Fisher et al., 2012). However, studies focused on the diverse ways people engage with nature in cities, suggest that the informal practices people carry out as part of their everyday lives may play an important and positive role in environmental stewardship (Gobster, 2007; Head and Atchison, 2009). Because these informal, everyday practices take place outside of organized programs, such as park clean-up days or "friends of the park" activities, they often go unrecognized (Smith et al., 2010; Martinez et al., 2011).

Use of informal environmental stewardship practices as a management tool could have important benefits for urban conservation.

\footnotetext{
* Corresponding author.

E-mail address: mclainrj@pdx.edu (R.J. McLain).

${ }^{1}$ Present address: Institute for Sustainable Solutions, Portland State University, 1600 SW 4th Avenue, Suite 110, Portland, OR, 97201, USA.

${ }^{2}$ Present address: University of Washington, Sea Grant Program/NOAA Northwest Fisheries Science Center, 3716 Brooklyn Avenue NE, Seattle, WA, 98105 , USA.

${ }^{3}$ Present address: School of Environmental and Forest Sciences, College of the Environment, University of Washington, Seattle, WA 98195 , USA.

${ }^{4}$ Present address: Independent consultant, Portland, OR, USA.
} 
Informal stewardship has demonstrated significance within low-income and underserved communities (Smith et al., 2010; Martinez et al., 2011; Jupp, 2012) whose members may face challenges participating in formal volunteer initiatives (Hobbs and White, 2016). Informal practices can take place in different types of urban spaces than formal volunteering and thus offer opportunities to expand the scope and geographies of urban stewardship (Hurley et al., 2008; Smith et al., 2010). Additionally, paying attention to informal stewardship practices can highlight previously invisible values, skills and capacities within local communities, offering opportunities to enhance resident's engagement with the natural world (Jupp, 2012; Krasny and Tidball, 2012).

This paper seeks to broaden the conversation about urban environmental stewardship by examining its intersection with everyday practices of urban nontimber forest products (NTFP) foraging. We define urban foraging as the harvest of non-timber forest products (NTFPs) such as wild berries, mushrooms, herbs, fallen branches, and tree fruits in city environments for food, medicine, fuel, craft materials, and other cultural uses. Humans have harvested NTFPs since time immemorial but foraging has only recently been recognized as an activity occurring in cities. Over the past decade, scientists have documented foraging practices in Baltimore (Jahnige, 2002), Charleston (Hurley et al., 2008; Hurley and Halfacre, 2010; Grabbatin et al., 2011), Philadelphia (Hurley et al., 2015), New York (McLain et al., 2013), and Seattle (Poe et al., 2013, 2014). In US cities, much of this activity takes place in parks and green spaces where foraging is commonly prohibited owing to concerns that it may negatively impact ecosystems (McLain et al., 2012; Poe et al., 2013). However, empirical evidence of the ecological impacts of urban foraging-either positive or negative-is limited. Moreover, exploratory research on urban foraging suggests that foragers may engage in activities similar to those employed by restoration and other vegetation management programs, such as removing invasive species; and transplanting and pruning native species (Jahnige 2002; McLain et al., 2013). Terada et al. (2010) examined the use of volunteers to replicate the traditional practice of foraging poles for firewood as a means for restoring Tokyo's satoyama forests. A limitation of this formal stewardship program was that the scale at which pole harvesting needed to occur far exceeded the capacity of volunteerbased programs. Terada et al. concluded that treating the satoyama as a working forest by permitting pole harvesting for personal or commercial use would be a useful complement to reliance on formal volunteer programs for achieving restoration goals.

Here we explore the potential for incorporating informal urban foraging activities into urban forest restoration programs using foraging and stewardship policies in Seattle, USA as a case example. Drawing on data collected during ethnographic research conducted in 2010 and 2011, we seek to answer three questions:

1.) What stewardship practices and norms are associated with foraging in Seattle?

2.) In what ways do those practices and norms complement or conflict with the Seattle Park and Recreation Department's management objectives, including its formal stewardship programs?

3.) What are key challenges to embracing urban foraging as a legitimate activity in urban green spaces, and what are the prospects for overcoming those challenges?

Although our research focuses on foraging practices in Seattle, the findings have broad applicability to other cities dependent on formal and informal public-private partnerships to achieve ecological restoration goals.

\section{Methods}

The study took place in Seattle, the largest city (pop. 608,660) in Washington State, and the economic center for the Puget Sound Region's 4.2 million inhabitants (U.S. Census, 2010). The region's moist, temperate climate provides favorable growing conditions for numerous plants and fungi as well as the possibility for humans to gather NTFPs year-round. Foraging is a popular activity among Seattlites: a study of Seattle area residents found that 26 percent gathered or collected products in nature settings as a form of recreation (City of Seattle, 2014).

Data for our study were collected through semi-structured interviews with 58 urban foragers and 18 land stewards, including 13 paid land managers and five volunteers who organize stewardship activities for park agencies or non-governmental organizations. The interview data were triangulated with participant observations of more than 80 organized foraging and stewardship activities, including guided foraging walks, forest and urban orchard steward work parties, wild mushroom forays, and urban forest commission meetings. Purposive snowball sampling was used to select foragers with an eye toward maximizing the range of variation in products harvested, foraging experience, and residence within Seattle. Foragers were asked to describe which species they collected, efforts they made to improve the productivity and habitat of gathered species, their involvement with formal stewardship groups, and their perspectives on how well city policies address foragers' needs and values. Land stewards were asked to describe the ecological impacts of foraging that they had observed and their perspectives on the challenges and opportunities associated with recognizing foraging as a legitimate activity in city parks. The data were coded using AtlasTI. Analysis of the forager interviews entailed coding and analyzing the data thematically so as to identify stewardship practices, norms, and ethics. Additionally, data from foragers and land stewards were analyzed to identify the range of views regarding the potential for using foraging as a tool to support park management and restoration goals.

\section{Results}

\subsection{Characteristics of foragers who participated in the study}

The foragers in our study ranged in age from 23 to 83 years old with an average age of 44 . Thirty-six were women and 22 were men. The majority (50) self-identified as White, Caucasian, Euro-American, or European. Two self-identified as Asian, two as Native American/White, one as Asian/White, one as White/Latino, and one as African-American. Most were highly educated with 44 having completed four or more years of higher education. The foragers were evenly distributed across income categories. Some had started to gather within the previous year, others had more than 60 years of experience; the average number of years of experience foraging was 24. Many harvested small quantities for personal use; however, roughly half earned some income from foraging, providing services such as guided foraging walks and the sale of value-added products. Products harvested were used for food, medicine, arts and crafts, fuel, and construction wood. Most harvested from multiple land use/habitat types, with parks, forests, and yards being the most common foraging sites. A total of 433 species of plants and 53 species of fungi were gathered, including 195 native plant species.

\subsection{Foraging practices and stewardship}

Three aspects of stewardship emerged from interviews with foragers about their harvesting practices in Seattle. One aspect had to do with the biophysical impact on plants, fungi and their habitat. A second aspect focused on the importance of knowledge acquisition and sharing in shaping foragers' understandings of how their actions affect plants. The third aspect concerned the ethics that influence how foragers interact with plants and the circumstances under which they consider plants or fungi "fair game" for harvesting. Table 1 summarizes key elements of the three aspects of foraging-related stewardship, including specific practices and examples of species affected.

Foragers used a variety of harvesting practices that fit the EPA's 
Table 1

Stewardship practices carried out by urban foragers in Seattle, WA.

Stewardship aspect and specific practices

1. Minimizing negative impacts to individual organisms and populations

- Informal area "closures"/rotations (Ex: Not harvesting in restoration areas because they are "young" systems; avoiding natural areas that are small in size)

- Timing harvest to reduce impacts on individual plants (Ex: Peeling madrone bark in August when it is peeling anyway)

- Selective harvest to ensure long-term viability of the organism or population (Ex: Minimal or no harvest if resource is scarce; application of 1-in-10 rule or 1-in-3 rule (harvesting only a tenth or a third of what is there) for more abundant species)

- Harvesting in ways that won't harm plants/fungi (Ex: Using a knife to cut off polypores, rather than pulling them off

2. Minimizing negative impacts to habitat

- Leaving some of the product for wildlife, birds, or other humans

- Limiting soil disturbance through use of special tools

- Stepping carefully when off-trail to minimize trampling

3. Species enhancement (improving reproduction and health of harvested species)

- Scattering seeds or spores

- Removing rotten and fallen fruit to minimize pests

- Transplanting

- Dividing and spreading bulbs

- Pruning diseased/dead parts of plants

- Weeding

- Mulching

4. Habitat enhancement

- Removing invasive species

- Picking up trash

- Improving trails

5. Knowledge acquisition and sharing

- Seeking knowledge from others about how to harvest sustainably

- Mentoring others in sustainable harvesting practices

- Generating community interest in plant or tree care

- Sharing recipes and products from gathered foods

6. Ethics of care

- Focusing on mindfulness and reciprocity

- Spending time with the plant, seeking its permission before harvesting

(2005, p. 1) definition of environmental stewardship as consisting of individuals or groups actively taking "responsibility to improve environmental quality and achieve sustainable results." To ensure a sustainable harvest, foragers used practices that aimed to minimize longterm detrimental ecological effects of harvesting and/or improve the well being of individual organisms, populations, or habitats. Within the impact minimization category, stewardship practices either aimed to reduce harm to individual plants and populations and/or broader negative ecological impacts. To minimize negative impacts on specific organisms and populations (Table 1, categories 1 and 2), foragers engaged in a practices such as deliberately choosing not to harvest in certain areas for ecological reasons, timing harvests to coincide with periods when plants were unlikely to be damaged by harvesting actions, or harvesting only plants or fungi present in abundance. To reduce negative ecological impacts, foragers engaged in practices such as being careful not to step on at-risk species when walking through an area or using special tools when removing bulbs.

Enhancement-oriented stewardship practices fell into two categories (Table 1, categories 3 and 4): those aimed at improving the health of individual organisms or populations and those directed at improving the foraged species' habitat. Techniques used included activities such as spreading seeds to new areas, splitting and spreading bulbs, and removing weedy species from around more desirable plants. Habitat improvement practices included activities such as removing invasive species and picking up trash. Nearly all of the foragers (50) described using practices to minimize negative impacts on or enhance a harvested species or its habitat. Most foragers (41) listed techniques aimed at minimizing negative impacts to plants. Twenty-four foragers used techniques for improving plant well being, 20 engaged in habitat improvement practices, and 18 described harvesting so as to minimize broader ecological impacts. The majority of foragers (44) used at least one practice that minimized impacts to plants or their habitat, 34 used at least one improvement-oriented practice, and 26 used at least one impact minimization and one improvement practice.

Acquiring and sharing ecological knowledge so as to be able to distinguish which practices are ecologically harmful was another important aspect of foraging stewardship. Foragers learned about plants and fungi in a variety of ways, including from field guides, internet websites, and blogs; through mentoring relationships with relatives or friends; by sharing knowledge with other foragers in the field; through participating in professional networks (e.g., herbalist guilds, landscaper associations) and foraging or craft-making associations (e.g., amateur mycological societies and basket weaver guilds); and by taking formal and informal classes. Nineteen of the interviewees participated in formal stewardship groups, with plant care or restoration-oriented groups being the most common (13 foragers), followed by food forest or fruit tree rehabilitation ( 7 foragers), and trail improvement groups ( 1 forager). Two participated in both formal restoration and food forest groups.

Several of the foragers taught wildcrafting or herbal healing classes; others conducted nature walks and foraging tours. Instructors emphasized the importance of imparting to their students the need for responsibility toward plants. A forager who runs a wildcrafting business and teaches wildcrafting, summarized her approach as follows:

[Foraging] can go either way, I mean harvesting can tend and prune...just like your garden. You can care for the environment if you're harvesting in a proper way, and then, on the other hand, I always say to my students, "When you harvest, it shouldn't look like you've been here when you leave." And if it looks like you've been there, then you're being destructive.

Teaching responsible harvesting also took place in less formal settings, such as parents mentoring their children in foraging etiquette. One forager drew attention to the role of informal encounters with passers-by as opportunities for teaching sustainable harvesting practices:

[I]f I'm harvesting something, you know, people are usually curious, so I'll spend a few minutes sharing knowledge or information with people, both about either wild edibles, herbal medicine, and sustainable harvesting practices, which I really think in engaging the community in wild harvesting in parks, for example, the education about sustainable harvesting practices is a critical component that needs to be there. And not only educating the public, but educating the park services.

This last statement about park employees needing education about sustainable harvesting practices was a common theme in the interviews with foragers.

\subsubsection{Ethics of care}

A third theme emerging from the interviews was the notion that stewardship includes having a mindset that it is important to harvest in ways that demonstrate respect for other species, other humans, and the environment. Caring for the environment is, in part, self-serving for foragers. On forager articulated the self-interest rationale, stating, "One primary reason [for harvesting carefully] is I'm going to come back to this place in the future so I don't want to damage it for myself." Another forager pointed out that self-interest serves as an incentive to use resource enhancement practices and limit the quantities harvested:

I think there's a lot of ethics that have to go into not trashing, not overharvesting. And you want to do that even if it's your own little patch, you'd want to make sure you don't overharvest because then it doesn't come back. And then you basically, if anything you want to encourage its growth and expansion.

However, as reflected in the following statement by another forager, motivations for taking care of foraged plants can also transcend individual self-interest: 
Table 2

Excerpts from foraging interviews illustrating the ethics of care.

\begin{tabular}{|c|c|}
\hline Forager & Language of care \\
\hline JM016 & When I harvest, I usually feel guilty if I don't do some kind of reparations or make amends; I definitely ask the plant if I should harvest it. \\
\hline LSU01 & I want to make sure I'm not harming the plant or any species near it. \\
\hline LSU02 & Yeah, it's really important if you wanna keep coming back; to kind of nurture your spot. \\
\hline LSU03 & $\begin{array}{l}\text { We really believe that being participants in nature nurtures that connection but along with that comes the responsibility [of] what our harvesting effects have not only } \\
\text { on the next year but generations to come. }\end{array}$ \\
\hline LSU04 & $\begin{array}{l}\text { My main reason for making products is to provide education, not necessarily that I want that to be my main business. I'd rather teach people to harvest and collect and } \\
\text { responsibly collect their own food and medicine. }\end{array}$ \\
\hline LSU06 & $\begin{array}{l}\text { And I'm really careful when I go in there. I'm not going to take everything that's there, just because the plants need to be able to recover, and if you kill them then you're } \\
\text { not going to get anything. So, judiciously gathering. }\end{array}$ \\
\hline MP06 & ...if people don't know what they're doing and don't respect the area where things are growing that they could wipe out, you know, a fragile environment. \\
\hline JM07 & $\begin{array}{l}\text { I'm always taking into account the impacts on the rest of the community, both the ecological community and the human community as well. I don't want my urban } \\
\text { foraging to have a negative impact. }\end{array}$ \\
\hline JM10 & I don't want to disturb anything to any great extent other than pick things so that they're able to grow back and it's not disturbing the area. \\
\hline LSU13 & $\begin{array}{l}\text { And then of course there's ethics to that, in the sense that if you overharvest then you will wipe out a stand, and then it makes it so that nobody gets any. So you got to } \\
\text { be careful with that kind of stuff. }\end{array}$ \\
\hline MP02 & ...know your place and [that] you're connected in a web of life that has a lot to give you but you should also respect and seek to maintain. \\
\hline MP04 & $\begin{array}{l}\text { And so I feel like, at least the foragers I know, I feel like it's a pretty educated group in how do you care for the wild and make sure that it's sustainable how you're doing } \\
\text { it. }\end{array}$ \\
\hline MP18 & We try not to bother nature too much. Just walk around. Usually, mushrooms that are in that place will be there all the time. \\
\hline MP03 & $\begin{array}{l}\text { Ethical harvesting just makes sense to me, and I kind of take it for granted because it's always made sense. If you want something you have to kind of treat it gently so } \\
\text { that it comes back if you want more. }\end{array}$ \\
\hline LSU08 & So it's like caretaking, being conscious of what is going to be sustainable \\
\hline LSU09 & Yeah, I try to spread some plants to the right habitat. I think that's a good thing to do. Especially when you've got a void. \\
\hline LSU11 & $\begin{array}{l}\text { And plus it kind of goes back to my sustainability. If I see twenty of something I will take one. So there has to be enough sustainability. There has to be enough of the } \\
\text { plant for me to harvest. }\end{array}$ \\
\hline LSU17 & Well, I don't really take the whole plant because I want it to be able to regenerate itself $\cdots$ So, I'll always leave some behind, you know, enough so that it can grow again. \\
\hline LSU21 & $\begin{array}{l}\text { You, you know, show no trace of you being there and then you plant the seed so that there's future generations of that plant growing in that area. I think it's very } \\
\text { important for us to be mindful of our impact on those communities. }\end{array}$ \\
\hline
\end{tabular}

I'm always taking into account the impacts on the rest of the community, both the ecological community and the human community as well. I don't want my urban foraging to have a negative impact.

For some foragers, an ethics of care for the land involves learning to give back to the land. One forager articulated this as follows: "You try to look at an area and see, try to think about what might be sustainable and also what might help improve the area." When talking about their harvesting practices, many foragers used phrases that reflected a "caring" mode of engagement with nature. Excerpts from foragers' interviews (Table 2) illustrate the extent to which the language of care infused foragers' descriptions of their activities.

A species' status as invasive or non-invasive influenced foragers' stewardship practices. Most foragers expressed few qualms about harvesting Himalayan blackberry (Rubus armeniacus Focke), Japanese knotweed (Polygonum cuspidatum Siebold \& Zucc.), or nettles (Urtica dioica L.), all of which the Parks Department considers invasive species and targets for eradication. Because such species are abundant and tolerant of high levels of harvest, foragers believed that harvesting them would have little negative ecological impact. Indeed, some foragers stated that removing them was a public service. One forager's comments about pulling blackberry roots exemplifies this view of invasive species:

I have no problem pulling blackberry ( $R$. armeniacus) roots because I'm like, 'Y'all don't belong here, you're taking over everything else'... and it's almost like you're helping to maintain that area, you're helping the other native plants in the area to be able to grow and thrive.

Foragers used a similar rationale to justify harvesting fruits and nuts from exotic tree species. Several foragers considered harvesting fruits to be a form of stewardship that supported the Parks' management objectives since it enhanced park aesthetics and safety while reducing the likelihood that fallen fruit would serve as vectors for pests and diseases that could harm the trees.

Foragers' views about harvesting native species were complex as some native species are invasive and crowd out other native species that foragers (and park managers) wish to encourage. Of the 51 foragers who provided input on how nativity affected their harvesting activities, roughly one-third (16) said they were less likely to harvest native species and took greater care when harvesting them. Another third (15) harvested native species more carefully, but expressed strong misgivings about using nativity as a harvesting decision factor. The remaining foragers (20) said they treated non-native species the same way they treated native species. These foragers argued that harvesting decisions should be based on a species' abundance, both on-site and regionally, its reproductive and growth characteristics, and its functionality within the ecosystem, rather than its native status.

Most foragers were positively disposed toward the Parks' forest restoration program. Of the 46 foragers who provided input on restoration project impacts on their activities, more than half (27) thought that such projects were beneficial or would be beneficial for harvesting in the long term. Benefits cited included: increased ease of access in areas where trails had been constructed, better visibility of mushrooms and understory plants in areas where ivy had been removed, and an anticipated increase over the long term in native plant species valued by foragers. Thirteen foragers reported that restoration activities had reduced their access to foraging sites. However, nine of these foragers expected their access to increase as the restored areas matured. The Parks' aggressive stance on eradicating $R$. armeniacus was the major aspect of the restoration program that foragers disagreed with. Several foragers were in favor of a more nuanced approach that would allow community groups to manage blackberry patches in nearby parks more intensively in place of eradication. Also of concern to many foragers was the potential exposure to toxins from the Parks' use of herbicides in restoration efforts (e.g., treatment of $P$. cuspidatum with herbicides).

The practices described in the previous section suggest that urban foraging has potential to have a positive impact on ecological systems in city parks. However, it is also important to understand the extent to which it might have negative impacts. When we asked the land stewards to describe the kinds of urban foraging that they had encountered, they described foraging in city parks as relatively uncommon and small in scale. Berries were the most common product they had seen being harvested in parks, followed by mushrooms, fruit, edible greens, and 
nuts. Two land stewards cited examples of foraging practices they had seen that they considered damaging. One park employee described having seen "whole sections" of Gaultheria shallon Pursh, a plant whose leaves are used in floral arrangements, clipped by foragers. However, he qualified his description stating that such behavior is "not as common-thank God-as it could be." To put this example in context, it is useful to know that $G$. shallon is a very fast-growing species that is highly tolerant of intense harvesting, and which professional foresters in the Pacific Northwest have actively sought-unsuccessfully-to eradicate for decades (Fraser et al., 1993). A long-time volunteer in the Forest Steward program provided a second example, stating that sometimes people took native plants from the park in which he did restoration projects. Several land stewards voiced concerns that foragers going off-trail might trample sensitive species or compact the soil; others stated that foraging of native berry bushes was potentially damaging as it could inhibit their natural regeneration and might reduce food for birds and wildlife. Despite their concerns, most of the land stewards condoned berry picking, as well as harvesting of other products such as wild mushrooms, fruits, and nuts. Thirteen land stewards admitted to foraging in city parks themselves. Even the land stewards with staunch anti-forager views sampled berries while working and encouraged other volunteers to do so as well.

\subsection{Land stewards' views about expanding opportunities for foraging in Seattle's parks}

All but two of the land stewards we interviewed were cautiously supportive of allowing low-level foraging in city parks or natural areas. Many land stewards thought that foragers could provide a service by doing land care work that the Parks Department lacks the resources to do. Types of work mentioned included harvesting fruit that would otherwise fall on the ground and serve as a vector for pests and disease, rehabilitating fruit trees suffering from years of neglect, and providing educational programs on native and edible plants and fungi. Land stewards also felt that allowing foraging would help the Parks Department promote its local food systems and food security goals. Most formal stewards envisioned this happening primarily through expanding foraging opportunities associated with the rehabilitation of the park system's existing stock of exotic fruit trees, as well as some additional fruit tree plantings. However, a few had a broader vision in which food production-including foraging-would eventually become integrated into forest restoration management strategies. Enhancing foraging opportunities was also viewed as a means by which the Parks Department could support the city's environmental justice goals. Specifically, some land stewards believed that by allowing foraging, the park system would see more use by first generation immigrants interested in maintaining homeland gathering traditions, as well as by Native Americans interested in maintaining or renewing their cultural traditions. Land stewards also viewed foraging as a potential environmental education tool that the Parks Department could use to further its goals of strengthening human connections with nature. Finally, land stewards saw foraging, with its potential to link local food systems, environmental sustainability, stewardship, health, and cultural traditions, as a potential means to strengthen the city's multi-functional ecosystem services approach to urban forest management.

Two of the land stewards interviewed strongly opposed relaxing the prohibition on foraging in parks. Both cited the long-standing "leaveno-trace" tradition of American parks as a justification for not legalizing foraging. They also believed that opening the parks to foraging was a "slippery slope" that would, in their view, lead to commercial harvesters destroying the resource. Other objections they raised included the risk of liability claims if foragers were to injure themselves while foraging in the parks, potential negative impacts on wildlife and vegetation, and incompatibility with a state law prohibiting private profitmaking from the use of park resources. Land stewards supportive of urban foraging also raised some of these concerns. However, the supportive land stewards expressed cautious optimism about being able to come up with workable solutions to these challenges.

\section{Discussion}

\subsection{Urban forest management and formal stewardship in Seattle}

Concerns about the long-term health of Seattle's urban forest during the 1990s led to the development of an Urban Forest Management Plan in 2007 (City of Seattle, 2007). The plan laid out a framework for increasing Seattle's canopy cover to more than 30 percent aggregated across the city by 2037. The plan was revised in 2013 to articulate a new vision of trees as "a shared community resource and as part of the natural urban ecology" (City of Seattle, 2013, p. 10). The revised plan's title, Urban Forest Stewardship Plan, reflects the Seattle Urban Forest Commission's belief that an environmental stewardship ethic should guide the city's efforts to improve Seattle's urban forest. The Stewardship Plan emphasizes the importance of individual and neighborhood actions for sustaining the urban forest and draws attention to the need to get "individuals, communities, and institutions to change their values, behaviors, and their attitudes about urban trees" (City of Seattle, 2013, p. 18). The Stewardship Plan includes food production and urban foraging among the functions and benefits of a healthy urban forest. The plan describes urban foraging as important because it "maintains traditions and social ties while deepening connections with nature", "offers positive physical and mental health benefits", and allows foragers to pursue food and health sovereignty and justice goals (City of Seattle, 2013, p. 33).

Seattle's extensive city park system, which includes developed parks and parks managed as natural areas, is a key component of the city's urban forest. The Seattle Parks and Recreation Department (hereafter referred to as Parks Department) has a dual mission of providing opportunities for park visitors "to play, learn, contemplate and build community" and promoting "responsible stewardship of the land" (City of Seattle, 2011, p. iii). Key strategies by which the Parks Department seeks to accomplish its mission include forest restoration and environmental education (City of Seattle, 2011). To meet its forest restoration goals, the department initiated the Green Seattle Partnership, a publicprivate partnership that recruits and trains volunteers to restore forested habitats in Seattle's park system. Forest Stewards are trained to direct other volunteers to remove invasive species, plant trees, and maintain native understory vegetation (City of Seattle, 2013). To mesh the Parks' environmental stewardship activities with its community food security goals, the Parks Urban Food System program partnered in 2010 with City Fruit, a local group whose mission includes restoring and expanding the fruit tree component of Seattle's urban forest. Through City Fruit, Seattle Parks implements an Urban Orchards Stewards program modeled after the Forest Steward program. The Urban Orchards Stewards program trains volunteers to rehabilitate neglected fruit and nut trees in city parks and seeks to improve public and private access to fresh fruit through providing tree care training, organizing a city-wide fruit harvest, and delivering harvested fruit to food banks. Seattle Parks also taps into formal stewardship programs to conduct inventory and monitoring. The land stewards who participated in our study identified volunteer recruitment and retention, particularly among low-income and minority communities, as key challenges in implementing the Parks' formal stewardship programs, challenges consistent with national trends in urban stewardship (Fisher et al., 2012). Practitioners have characterized formal stewardship in Seattle as multi-layered, with individuals acting on the basis of values (e.g. environmental ethics, personal ethics, and concern for community) and organizations pursuing goals (e.g. environmental improvement and community building) (Romolini et al., 2012).

Our field observations and interviews with foragers in Seattle indicated that contrary to many land managers' pre-conceptions (Hurley et al., 2015), many foragers engaged in practices that fit common 
Table 3

Foraging practices which are aligned with the Parks Department's objectives.

Removal of products that reduce the Parks' maintenance costs

- Examples: harvesting fallen nuts in playfields, harvesting fruits that would otherwise rot, attracting pests and creating safety hazards

Removal of species the Parks Department categorizes as undesirable

- Examples: $R$. armeniacus, Hedera helix L.

Removal of plant material slated for removal by park crews

- Examples: Harvesting downed wood or pruned branches that the Parks Department would otherwise need to haul away

Encouragement of species the Parks Department perceives as desirable

- Examples: Seeding of native plants, live-stick planting of native plants

Foraging activities that further the Parks Department's environmental education objectives

- Example: Leading edible plant walks

definitions of stewardship. Not only did most foragers take steps to minimize damage to the plants they harvest and the ecosystems they work within, but they also sought to enhance the health of plants and their habitats. They did so using diverse practices, many of which are identical to practices recommended in formal stewardship programs. However, the concept of stewardship as articulated by the foragers in our study integrates physical practices, knowledge drawn from both scientific and experiential knowledge traditions, and an ethics of care. This multi-dimensional concept of stewardship matches that described for rural NTFP harvesters in the southeastern (Emery, 2001) and northeastern United States (Baumflek et al., 2010). From a practical standpoint, our findings suggest that, in aggregate, urban foragers' everyday informal stewardship activities could complement the work carried out by formal stewardship groups and the Parks Department's professional staff (Table 3). However, to realize the full potential of the benefits associated with informal foraging-based stewardship, two major challenges will need to be overcome.

Perhaps the greatest challenge will be overcoming the "leave-notrace" paradigm among park professionals and moving beyond the Parks Department's current focus on restoring native species and removing non-native species. This paradigm does not adequately take into consideration the socio-ecological functions that exotic species may have in novel ecosystems (Kowarik, 2011), such as green spaces in dense urban areas. Our interviews with land stewards suggest that this may be less of a challenge than it would have been a decade ago. A move away from the "leave-no-trace" norm governing park use is already occurring within the Seattle Parks Department, fueled in part by the city's influential urban agriculture movement. Also promising is the shift within the fields of ecology, forestry, and urban planning toward seeing cities as socio-ecological systems, with humans considered integral-and positive-components of urban green spaces (Pincetl, 2015). In Seattle, the opportunities for the Parks Department to engage with foraging in a positive way are doubly enhanced by the already blurry distinction between land stewards and foragers. As revealed in our interviews, many land stewards forage and many foragers participate in formal stewardship programs. This blurriness between stakeholder categories holds promise for facilitating the building of stronger links between formal and informal stewardship traditions. Doing so however, will require identifying the areas where foraging and park management objectives are aligned and where they are incompatible. Accomplishing these tasks also will require developing urban forest governance processes that involve foragers in decisions about urban green space management. In some cases trade-offs may need to be made between species which are of value to foragers, but which the Parks Department considers detrimental. The Himalayan blackberry is a classic example of a species for which the interests of foragers and the Parks Department are widely divergent. However, eradication is not the only way to manage invasive species, and experiments with new management institutions, such as community-managed $R$. armeniacus or $U$. diotica patches (perhaps using an "adopt-a-patch" approach) offer promise for win-win solutions.
A second challenge is how to ensure that foraging is done at scales and using practices that are sustainable in the context of a densely populated urban area with limited green space used for many purposes. A concern voiced by foragers and land stewards alike was that if foraging becomes a mainstream activity, new foragers might lack the extensive knowledge that long-term foragers have of local ecosystems. If social mechanisms for transmitting knowledge about low-impact practices and imparting sustainable land care ethics are not in place, there is a risk that foraging will occur in ways that are ecologically harmful. Until studies that document the long-term impact of foraging have been done, however, the level of risk that foraging poses to urban species or habitats is unknown. A promising model for managing that risk is a wild mushroom monitoring project established by a coalition of commercial mushroom harvesters and environmental justice groups in the early 2000 s in central Oregon (Fernandez-Gimenez et al., 2008). The project used a field-based, community-designed "ethics of care" approach to a community outreach program aimed at educating harvesters about sustainable harvesting techniques and low-impact use of the woods. Another model is the use of voluntary forager codes, an approach that is being used in England's New Forest, a national park within easy access of London that receives some 13 million visitors per year (http://www. forestry.gov.uk/forestry/INFD-6E3GAZ). The voluntary foragers' code model also has been implemented in Scotland to govern the harvest of wild mushrooms (Dyke and Emery, 2010). The overlap that already exists between informal and formal stewards in Seattle provides a foundation for partnerships that have potential to develop ecologically viable approaches to a forager-friendly park system. Indeed, the collaborations that have emerged in Seattle around urban orchards and food forests during the past five years point to the likelihood of successful compromises.

\section{Conclusion}

The foragers who participated in this study emphasized the importance of stewardship practices involving caring for plants in a holistic way, including non-native plants. This approach contrasts with much of the ecological literature on stewardship and many formal stewardship programs that emphasize native species restoration and invasive and exotic species removal. The restoration/removal approach is a leftover from 20th century ecology, which focused on understanding native tree and plant structure in wildland settings (Choi, 2007). In densely populated urban areas, ecological structures and functions have been so greatly altered that scientists are now thinking of them as novel ecosystems with new and enduring structures and functions (Kowarik, 2011). In such environments, a restoration approach driven by species' origins is unlikely to be successful in the long run. Instead, it is important to focus on the ecological services that novel ecosystems already do or could provide, and acknowledge the positive contributions that humans can make to those ecosystems (Pincetl, 2015). The long term sustained commitment of many foragers can support stewardship programs. By embracing foraging, the Parks Department has the opportunity to capitalize on foragers' extensive local ecological knowledge, using it to inform more formal stewardship practices and support holistic urban natural areas management.

\section{Acknowledgements}

We thank the foragers and formal stewards who gave so graciously of their time and knowledge. We thankPatrick Hurley, Marla Emery, Susan Charnley, and Joyce LeCompte-Mastenbrook for their intellectual contributions throughout the study, and Lee Greer for editing assistance. Funding was provided under the American Recovery Act by the USDA-Forest Service, PNW Research Station under JVA \#: PNW $10 \mathrm{JV}$ 11260489-024 and through follow-on funding through Contract AG046W-P-12-0054. 


\section{References}

Asah, S.T., Blahna, D.J., 2013. Practical implications of understanding the influence of motivations on commitment to voluntary urban conservation stewardship. Consery. Biol. 27, 866-875.

Baumflek, M.J., Emery, M.R., Ginger, C., 2010. Culturally and Economically Important Nontimber Forest Products of North America. United States Department of Agriculture, Forest Service, Northern Research Station, Burlington, Vermont General Technical Report NRS-68.

Campbell, L., Wiesen, A., 2011. Introduction. In: Campbell, L., Wiesen, A. (Eds.), Restorative Commons: Creating Health and Well-being Through Urban Landscapes. General Technical Report NRS-P-39. United States Department of Agriculture, Forest Service, Northern Research Station, Newton Square, Pennsylvania, pp. 11-25.

Choi, Y.D., 2007. Restoration ecology to the future: a call for new paradigm. Restor. Ecol. 15 (2), 351-353.

City of Seattle, 2007. Urban Forest Management Plan. Urban Forest Coalition, Seattle (Retrieved 08-07-2017). http://www.seattle.gov/trees/docs/Final_UFMP.pdf.

City of Seattle, 2011. Seattle's Parks and Recreation 2011 Development Plan. Parks and Recreation Department, Seattle (Retrieved 08-07-2017). https://www.seattle.gov/ Documents/Departments/ParksAndRecreation/PoliciesPlanning/2017Plan/plan. 2011_ADOPTED.pdf.

City of Seattle, 2013. Urban Forest Stewardship Plan. Urban Forestry Commission, Seattle (Retrieved 08-07-2017). http://www.seattle.gov/trees/docs/2013\%20Urban \%20Fores\%20Stewardship\%20Plan\%20091113. pdf.

City of Seattle, 2014. Parks Legacy Plan: Goals and Strategies Parks and Recreation Department, Seattle. (Retrieved 08 07.2017) . (check to see if this was a quote - page numbers). https://www.seattle.gov/Documents/Departments/ ParksAndRecreation/PoliciesPlanning/PlanningParksLegacyPlan.pdf.

Connolly, J.J., Svendsen, E.S., Fisher, D.R., Campbell, L.K., 2013. Organizing urban ecosystem services through environmental stewardship governance in New York City. Landscape Urban Plann. 109, 76-84.

Dyke, A., Emery, M.R., 2010. NTFPs in Scotland: changing attitudes to access rights in a reforesting land. In: Laird, S.A., McLain, R.J., Wynberg, R.P. (Eds.), Wild Product Governance: Finding Policies That Work for Non-timber Forest Products. Earthscan, London, UK, pp. pp. 135-154.

Environmental Protection Agency (EPA), 2005. Everyday Choices: Opportunities for Environmental Stewardship. EPA Innovation Action Council, Washington D.C (Retrieved 08-07-2017). https://archive.epa.gov/stewardship/web/pdf/rpt2admin. pdf.

Emery, M.R., 2001. Who knows? local non-timber forest products knowledge and stew ardship practices in northern Michigan. J. Sustainable For. 13 (3/4), 123-139.

Fernandez-Gimenez, M.E., Ballard, H.L., Sturtevant, V.E., 2008. Adaptive management and social learning in collaborative and community-based monitoring: a study of five community-based forestry organizations in the western USA. Ecol. Soc. 13 (2), 4 (Retrieved 08-07-2017). http://www.ecologyandsociety.org/vol13/iss2/art4/.

Fisher, D.R., Campbell, L.K., Svendsen, E.S., 2012. The organisational structure of urban environmental stewardship. Environ. Polit. 21, 26-48.

Fraser, L., Turkington, R., Chanway, C.P., 1993. The biology of Canadian weeds. Gaultheria shallon pursh. Can. J. Plant Sci. 73, 1233-1247.

Gobster, P., 2007. Urban park restoration and the museumification of nature. Nat. Cult. 2, 96-114.

Grabbatin, B., Hurley, P., Halfacre, A., 2011 'I still have the old tradition': the co-production of sweetgrass basketry and coastal development. Geoforum 42, 638-649.

Head, L., Atchison, J., 2009. Cultural ecology: emerging human-plant geographies. Progr. Hum. Geogr. 33, 236-245.

Hobbs, S.J., White, P.C.L., 2016. Motivations and barriers in relation to participation in biodiversity recording. J. Nat. Conserv. 20 (6), 364-373.

Hurley, P.T., Halfacre, A.C., 2010. Dodging alligators, rattlesnakes, and backyard docks: a political ecology of sweetgrass basket-making and conservation in the South Carolina lowcountry, USA. GeoJournal 76, 383-399.
Hurley, P.T., Halfacre, A.C., Levine, N.S., Burke, M.K., 2008. Finding a disappearing nontimber forest resource: using grounded visualization to explore urbanization impacts on sweetgrass basketmaking in Greater Mt. Pleasant, South Carolina. Prof. Geogr. 60, 556-578.

Hurley, P.T., Emery, M.R., McLain, R., Poe, M., Grabbatin, B., Goetcheus, C., 2015. Whose urban forest? the political ecology of gathering urban nontimber forest products. In: Isenhour, C., McDonogh, G., Checker, M. (Eds.), Sustainability in the City: Myth and Practice. Cambridge University Press, New York, pp. 187-212.

Jahnige, P., 2002. Hidden bounty of the urban forest. In: Jones, E.T., McLain, R.J., Weigand, J. (Eds.), Nontimber Forest Products in the United States. University of Kansas Press, Lawrence, Kansas, pp. 96-107.

Jupp, E., 2012. Rethinking local activism: 'cultivating the capacities' of neighbourhood organising. Urban Studies 49, 3027-3044.

Kowarik, I., 2011. Novel urban ecosystems, biodiversity, and conservation. Environ. Pollut. 159, 1974-1983.

Krasny, M.E., Tidball, K.G., 2012. Civic ecology: a pathway for earth stewardship in cities. Front. Ecol. Environ. 10, 267-273.

Martinez, I.L., Crooks, D., Kim, K.S., Tanner, E., 2011. Invisible civic engagement among older adults: valuing the contributions of informal volunteering. J. Cross Cult. Gerontol. 26, 23-37.

McLain, R., Poe, M., Hurley, P.T., Lecompte-Mastenbrook, J., Emery, M.R., 2012. Producing edible landscapes in Seattle's urban forest. Urban For. Urban Greening 11, 187-194.

McLain, R.J., Hurley, P.T., Emery, M.R., Poe, M.R., 2013. Gathering wild food in the city: rethinking the role of foraging in urban ecosystem planning and management. Local Environ. 19, 1-21.

McMillen, H., Campbell, L.K., Svendsen, E.S., Reynolds, R., 2016. Recognizing stewardship practices as indicators of social resilience: in living memorials and in a community garden. Sustainability 8, 775 .

Moskell, C., Allred, S.B., 2013. Integrating human and natural systems in community psychology: an ecological model of stewardship behavior. Am. J. Community Psychol. 51, 1-14.

Pillemer, K., Fuller-Rowell, T.E., Reid, M.C., Wells, N.M., 2010. Environmental volunteering and health outcomes over a 20-year period. Gerontologist 50, 594-602.

Pincetl, S., 2015. Cities as novel biomes: recognizing urban ecosystem services as anthropogenic. Front. Ecol. Evol. 3, 140. http://dx.doi.org/10.3389/fevo.2015.00140.

Poe, M.R., McLain, R.J., Emery, M., Hurley, P.T., 2013. Urban forest justice and the rights to wild foods, medicines, and materials in the city. Hum. Ecol. 41, 409-422.

Poe, M.R., Lecompte, J., McLain, R., Hurley, P., 2014. Urban foraging and the relational ecologies of belonging. Social Cult. Geogr. 15, 901-919.

Romolini, M., Brinkley, W., Wolf, K.L., 2012. What Is Urban Environmental Stewardship? Constructing a Practitioner-Derived Framework. United States Department of Agriculture, Forest Service, Pacific Northwest Research Station, Portland, Oregon Research Note PNW-RN-566.

Romolini, M., Grove, J.M., Locke, D.H., 2013. Assessing and comparing relationships between urban environmental stewardship networks and land cover in Baltimore and Seattle. Landscape Urban Plann. 120, 190-207.

Sanderson, E.W., Huron, A., 2011. Conservation in the city. Conserv. Biol. 25, 421-423.

Smith, F.M., Timbrell, H., Woolvin, M., Muirhead, S., Fyfe, N., 2010. Enlivened geographies of volunteering: situated, embodied and emotional practices of voluntary action. Scot. Geogr. J. 126, 258-274.

Terada, T., Yokohari, M., Bolthouse, J., Tanaka, N., 2010. Refueling Satoyama woodland restoration in Japan: enhancing restoration practice and experiences through woodfuel utilization. Nat. Cult. 5, 251-276.

U.S. Census Bureau, 2010. Profile of General Population and Housing Characteristics. (Retrieved 08-07-2017). http://factfinder2.census.gov/faces/tableservices/jsf/ pages/ productview.xhtml? fpt $=$ table.

Wolf, K.L., Blahna, D.J., Brinkley, W., Romolini, M., 2013. Environmental stewardship footprint research: linking human agency and ecosystem health in the Puget Sound region. Urban Ecosyst. 16, 13-32. 